\title{
Impact of the Omnibus Law/Job Creation Act in Indonesia
}

\author{
${ }^{1}$ B. F. Sihombing, ${ }^{2}$ Adnan Hamid \\ ${ }^{1}$ Lecturer in Law Science - Faculty of Law - Universitas Pancasila (UP) Jakarta \\ ${ }^{2}$ Deputy Dean 2 of the Faculty of Law, Universitas Pancasila, (UP) Jakarta
}

\begin{abstract}
The purpose of this research is to analyze the impact of the Omnibus Law/Job Creation Act related to the discussion process and post-endorsement by the legislature, the House of Representatives of the Republic of Indonesia. This research uses the normative juridical method, which is a legal research conducted by examining library materials. or secondary data and carried out with descriptions, measurements and accurate reporting of the characteristics of some of the phenomena under study. The findings of this study are that the government and legislature in the process and discussion tend to conflict with the 1945 Constitution article 1 paragraph (3), article 27 paragraph (1), and article 28 paragraph (5) and Law No.12 of 2011. regarding the Formation of Legislative Regulations as updated by Law No.15 of 2019 . Pancasila as a philosophische grondslag is stated in the Preamble of the 1945 Indonesian Constitution which means that Pancasila is positioned as a source of constitutional law in Indonesia, is an inspiration for the formation of the rule of law in Indonesia. As a result, civil society organizations oppose and reject this regulation so that it is hoped that President Joko Widodo can issue a Government Regulation in Lieu of Law.
\end{abstract}

Keywords: Pancasila, 1945 Constitution, Law No.12 of 2011, Law No.15 of 2019, Omnibus Law/Job Creation Act.

\section{Introduction}

Indonesia is a state based on law as stated in the 1945 Constitution (UUD 1945) article 1 paragraph 3 which reads: "The State of Indonesia is a State of Law". The Unitary State of the Republic of Indonesia as a constitutional state based on Pancasila has the aims and objectives, to realize a safe, peaceful, prosperous and orderly state life and the legal position of every citizen is guaranteed so that a harmony, balance and harmony between individual interests and interests group (community) can be reached. Then, the 1945 Constitution adheres to the teachings of the Trias Politica. In the 1945 Constitution, state power is segregated, and each state power consists of: (1) a legislative body, namely the body that is tasked with forming laws; (2). executive body, namely the body in charge of implementing laws; and (3) the judiciary, namely the body in charge of overseeing the implementation of laws, examining and judging them. Pancasila is positioned as a basic norm (grundnorm) or state fundamental norm (staatfundamentalnorm) in the level of legal norms in Indonesia. Furthermore, Pancasila is described in various existing laws and regulations such as: laws, regulations, decisions, government policies, development programs, and other regulations which are essentially instrumental values as the elaboration of the basic values of Pancasila (Ihsan, $2008: 51$ ).

Thus, the 1945 Constitution and the Pancasila philosophy contain norms that require the entire contents of laws and regulations to oblige the government and other state administrators both at the central and regional levels as well as party organizers must be able to orientate and have implications for the formation of a just life structure. for all people covering ideology, politics, economy, social, culture, law and human rights (IPOLEKSOSBUDKUMHAM). However, the reality that is currently happening is that there are demonstrations against the ratification and urging President Jokowi to issue a Government Regulation in Lieu of Law (Peraturan Pemerintah Pengganti Undang - Perppu) to cancel the Omnibus Law / Job Creation Act (OL / JCA) which was passed into law by the House of Representatives of the Republic of Indonesia (DPR RI) on Monday, October 5, 2020. However, the actual fact that occurred was that the pros and cons 
arose against the OL / JCA and which is a critical issue of OL/JCA so that it becomes a substantive question is whether this OL / JCA is in line with the 1945 Constitution and the Pancasila philosophy?

According to article 3 of the Omnibus Law / Job Creation Bill 2020 which was ratified by the Indonesian Parliament that the purpose of this law, OL/JCA is to create the widest possible employment opportunities for the Indonesian people evenly throughout the territory of the Republic of Indonesia in the context of fulfilling the right to a decent living through the convenience and protection of micro, small and medium enterprises (UMK-M) as well as cooperatives, enhancing the investment ecosystem, ease of doing business, increasing protection and worker welfare, Central Government investment and accelerating national strategic projects (Daud Silalahi \& Lawencon Associates "DSLA", 15 April 2020). In this case, the purpose of OL/JCA can be interpreted as being able to encourage and increase Indonesia's economic growth which tends to slow down due to the trade war between America and China and is further exacerbated by the Covid-19 epidemic. released by the World Bank in September 2019 in Meilani (2019: 19) states that the global economic slowdown that occurs in countries such as the United States (US), Germany, Britain, and China can cause the risk of a world economic recession, and this condition can impact on the economic slowdown.According to Lewis (2013) in Alawamleh et.al, (2019: 3), economic growth is an increase in the ability of an economy to produce goods and services relative to the initial period or the previous period. This can be measured by measuring the percentage change in gross domestic product (GDP) realm of a country. The Central Statistics Agency (Badan Pusat Statistik) stated that economic growth in 2019 was 5.02 percent., There was a slowdown compared to the previous year with 5.17 percent in 2018 and in 2017 at 5.07 percent (liputan6.com. 05 Feb 2020). Therefore, the government needs strategic and urgent efforts to be implemented immediately in order to accelerate increased investment and boost Indonesia's economic growth by carrying out structural reforms through improving the investment ecosystem, making efforts to simplify all business permits in order to attract and bring in foreign investors to invest in Indonesia so that can open up jobs as much as possible.

Then, employment is a strategic issue and very important for economic growth because through the opening of employment it becomes a determinant of a country's political stability. Because, as long as people are busy with their work and able to meet their own needs, their morale is high and everything is stable, and jobs create income which in turn creates production and investment. Therefore, the government's efforts to eliminate slow, convoluted licensing matters, moreover there are illegal levies (pungli) which indicate corrupt behavior by government administrators both at the regional and central levels according to the government's perspective that OL / JCA is a solution to remove these investment barriers. In this case, investment is a key factor in creating jobs. This view is emphasized by the Investment Coordinating Board (BKPM) in Meilani (2019: 20) which states that there are at least five obstacles that are often faced by investors in investing in Indonesia that make foreign investment interest in Indonesia decrease.

The five obstacles are: (1) convoluted regulations; (2) difficult land acquisition; (3) uneven public infrastructure; (4) taxes and other non-fiscal incentives that do not support investment; and (5) inadequate skilled workforce. However, on the other hand, especially from various non-governmental perspectives, experts assess that the OL / JCA Draft has drawn a lot of criticism (Hamid, 2020: 237).Furthermore, various contra parties stated that OL / JCA was considered to contain many controversial articles and only concerned the interests of investors (Kompas.com.06Okt2020). Amnesty International Indonesia considers that (1) the articles in the QL / JCA can threaten the right of everyone to have fair and pleasant working conditions, contrary to the principle of non-retrogression in international law; (2) the legislative process, the preparation of OL / JCA is not transparent, there is no honest and open interaction between government authorities and community groups regarding its formulation; because this is guaranteed in Article 25 of the International Covenant on Civil and Political Rights (ICCPR). The voice and aspirations of labor and workers groups should be the main consideration of the government and the DPR; (3) the substance of OL / JCA has the potential to violate human rights (HAM) and contradicts Indonesia's international obligations to protect human rights, especially regarding the right to work and rights at work (Hamid in amnesty.id/ August 19,2020). Therefore, various contra parties demanded that OL / JCA be immediately revoked.

According to Nugraha (2020), as a legal democracy, Indonesia must be committed to ensuring public participation as a prerequisite for passing laws because logically, affected people must be allowed to speak their minds and be involved in processes such as labor, women and indigenous peoples. groups that will be 
greatly affected This view is in line with Roscoe Pound in Fuadi (2013: 48), which states that law is basically the will of the public, so it is not just law in the sense of law in books. Sociological Jurisprudence shows a careful compromise between written law as a requirement of the legal community for the creation of legal certainty (positivism law) and living law as a form of appreciation for the importance of the role of society in law formation and legal orientation. Then, Eugen Erhlich in Huijbers (1988: 213) which states that the actual social-norms that govern all aspects of society, namely living law and law are subject to certain social forces and positive law cannot be effective if it is released from social conditions., because order in society is based on social recognition of the law and not because of its official application by the state so that only positive laws that are in line with the living law will prevail in society (Eugen Erhlich in Dror, 1969: 92)

However, ironically, the government and legislature decided to discard public opinion and make laws for the benefit of the oligarchy as a result civil society organizations shouted skepticism about the omnibus law, because it would undermine the efforts of the labor movement, encourage modern slavery, destroy the environment, marginalize the most marginalized groups, open up opportunities for corruption. and criminalization to facilitate business entities so that the Omnibus is very useful for people who are in the vortex of power (Nugraha, 2020) .

Based on the description above, there is a gap in this study, between the pros and cons of the Omnibus Law / Job Creation Law. (OL / JCA) as follows:

1. Why is the government making the Omnibus Law / Job Creation Law. (OL / JCA)?

2. What is the impact of the Omnibus Law / Job Creation Law. (OL / JCA) after being passed by the Legislative, the House of Representatives?

\section{Methodology}

This research uses the normative juridical method, which is a legal research carried out by examining library materials or secondary data (Soekanto \& Mamudji, 2006: 13-14) and is carried out in a description, measurement and accurate reporting of the characteristics of some populations or phenomena studied ( .Babbie, 1986: 81). The steps taken in this research are as follows: literature study, examining secondary data in the form of: primary legal materials and secondary legal materials. Primary legal materials include the 1945 Constitution of the Republic of Indonesia, the Draft Omnibus Law / Job Creation Law. (OL / JCA), and various other related laws and regulations. Meanwhile, secondary legal materials are obtained through the study of research results, books, scientific journals and jurisprudence, as well as other library materials that discuss Omnibus Law. Therefore, in order to get a more complete and comprehensive understanding, a comparative study was carried out on secondary data related to the omnibus law that has been implemented in various other countries.

\section{Literature Review}

According to Black's Law Dictionary, the Omnibus Law is relating to our dealing with numerous objects or items st once, including many things or having various purposes. (Garner, 1999: 1116). Meanwhile, the meaning of omnibus bil according to Black's Law Dictionary (Garner, 1999: 157) is as follows: (1) A single bill containing various distinct matters, usu, drafted in this way to force the executive either to accept, all tje unrelated minor provisions or to veto the major provision; (2). A bill that deals with all proposals relating to a particular subject, such as an "omnibus judgeships bill" covering all proposals for new judgeship ir an "omnibus crime bill" dealing with diffrent subjects such as new crimes and grants to states for crime control. This view is in line with Bierscbach (2017) which states that omnibus bills are formal proposals to change laws that are voted on by rank and file lawmakers and sent off to the executive branch for final approval. The difference with omnibus bills is they contain numerous smaller bills, ostensibly on the same broad topic. Take the omnibus tax bill as an example: It may include changes on everything from income, corporate, and sales taxes, but all of those issues can fit under the large umbrella of taxes. Omnibus law can simply be interpreted as a single law that can change several laws at once, and there are three circumstances for practicing the omnibus law, namely the law to be changed is directly related, the law to be changed is not directly related, and the laws to be changed are not related but in practice intersect (Suriadinata, 2019: 115). According to Dodek (2016: 9), Omnibus bills are efficient because they permit the bundling of enactments or amendments to multiple statutes in a single bill. When these relate to the same subject matter, they may facilitate the parliamentary consideration of that particular area. According to Daud Silalahi \& Lawencon 
Associates "DSLA", 15 April 2020), omnibus law is defined as a method used to replace and / or revoke provisions in law or rearrange several provisions in a statute into one statute or thematic as an effort to create work through efforts to facilitate, protect, and empower micro, small and medium enterprises (MSMEs), increase the investment and investment ecosystem of the Central Government and accelerate national strategic projects.

The omnibus law is profitable in terms of cost and time (Krutz, 2001: 22). According to experts in Krutz, 2001: 211) states that Omnibus bills take several forms, including program reauthorizations, budget reconciliation bills, continuing appropriations legislation, and original bills. Bills unifying diverse topics are not new. Leaders have traditionally used riders to move controversial proposals through the legislative process and avoid the need to construct coalitions in favor of the particular measure. In contemporary times, however, rolling many measures into one bill is more common, the resulting bills span a greater number of diverse policy areas, and significant policy change occurs through omnibus bills (Mayhew 1991; Oleszek 1996; Sinclair 1997; Smith 1989). Although members often attempt riders to kill legislative initiatives, leaders assemble omnibus bills in order to get something passed. The omnibus tactic is powerful because it enables leaders to focus attention away from controversial items to other issues that enjoy widespread support. The bigger bill has its own locus (or multiple loci) of attention and is more likely to have the broad support needed for passage Kirchhoff and Tsuji, 2014).

Contrary to the opinion of Krutz (2001), Kirchhoff \&. Tsuji (2014: 117-118) states that omnibus law as governmental initiatives are positively worded and presented to the public (with millions of taxpayer dollars being spent on advertising campaigns), in practice, what can be seen is that there is nothing 'responsible 'about Responsible Resource Development. Our analysis implies that a number of these governmental initiatives serve to further weaken Aboriginals' capacities to participate in the resource development review processes, increase discretionary powers that further reduce the predictability of the review process and remove environmental protection that have been in place to safeguard the health and livelihood of all Canadians (Aboriginal and non-Aboriginal). Given the current focus on resource development by the Government of Canada, it is not unreasonable to conclude that the governmental initiatives discussed in this paper further silence the people who are most affected by resource development. Finally, the rhetoric behind the Canadian 'Responsible Resource Impact Assessment and Project Appraisal 117 Development' (particularly when applied in the context of northern Ontario) ends up benefiting only a few developers and shareholders living thousands of miles away from where resource development occurs and affect local communities, while the risks and potential adverse impacts and risks are left to local communities living in these remote areas .

According to Michael (2020: 165), legal studies in America, the omnibus law is known as the omnibus bill and is the freedom to form a regulation from the legislature. The members are free to determine how to determine a goal and any way that can be done to achieve that method. But the problem is whether this method is illegal or legal? According to Nightingale (2016: 125), there are various objections to the Omnibus Law because from the perspective of Indonesian law, the Omnibus Law is a statutory regulation that discusses many things, problems and programs that do not have to be related, and therefore usually very complex and long Law as law enforcement must be related to democracy. The concept of democracy is a separate keyword in the field of political science, upholding the right of everyone to have an opinion, to have a certain ideology, and to have a certain identity and to respect every opinion that comes out of everyone's mind. (Nightingale, 2016: 125).According to Busroh (2017: 229), Indonesia has passed a government regime from the Old Order government to the Reform Order, and the replacement of the President and government cabinet which resulted in the birth of many laws and regulations according to the wishes of each government in power at that time, causing regulatory problems where there are several overlapping laws and regulations (Hamid, 2020: 224-225) which results in a policy conflict between one ministry / department and another ministry / department. According to Hamid (2020: 224-225), the lack of legal clarity in various laws becomes an obstacle for investment so that this is the concern of the government and practitioners in the investment sector and critical reform is needed (The Socioeconomic Report - SER, 2017: 3) to resolve these regulatory issues in order to boost the investment and investment ecosystem of the Central Government and accelerate national strategic projects. 
According to the Asia Securities Industry and Financial Markets Association - ASIFMA (2019: 81) that the need for global investors, internally is for better consistency by considering international standards for financial regulation as follows: (1) policy makers can provide a level of equality, comparability and appropriate predictability in regulatory outcomes with other jurisdictions; (2) financial institutions, both domestic and international, are better able to invest, operate and offer cross-border services without unnecessary barriers and complexity, freeing up efficient investment flows to where they are most needed; (3) companies, investors and retail customers will be able to access services more safely and efficiently with less risk of financial instability.Therefore, to respond to this condition, a proper legal breakthrough is needed and one way out is through the concept of the omnibus law (Busroh, 2017: 229). The same view is also expressed by Azhar (2019: 170-178) which states that application of the concept of omnibus law as a hyperregulatory solution to synchronization and harmonization through simplification or simplication of laws and regulations in Indonesia (Setiadi (2018: 327).

\section{Discussions and Results}

\section{History of Application of Omnibus Law in the United States and in various countries}

Based on historical data, the Omnibus Law can be interpreted as a law that targets a major issue that may cut and or revise a law and is widely implemented in various countries that adhere to the common law legal system (anglo saxon). According to Redi (2020), it is recorded that the date is 1888 when the practice of omnibus law first appeared in the United States, and the term used is the omnibus bill. The cause is a private agreement related to the separation of two railroads in America and in 1967 the design of this method became popular which at that time the United States Minister of Justice, Pierre Trudeau introduced the Criminal Law Amendement Bill, which was to change the criminal law law and cover many issues. . Omnibus Law or known as the Omnibus Bill which is often used in countries that adhere to a common law system such as the United States in making regulations, namely making a new Law (UU) to amend several laws at once (Suriadinata, 2019: 115; Darmawan, 2020:17) In the context of the application of the omnibus law, Cabote (2001) states that the Philippines has implemented the omnibus law in the investment sector by issuing the omnibus investment code of 1987, and through the omnibus investment code of 1987, investors will be given a number of incentives and basic rights. which guarantees their business in the Philippines. The purpose of implementing The Omnibus Investments Code of 1987 (Executive Order No. 226, as amended), which is implemented by the Philippine Board of Investments (the "BOI"), provides a comprehensive set of incentives for local and foreign enterprises engaged in activities considered by the Philippine government as high priority for national development (Cabote, 2001).

According to Darmawan (2020: 19), the use of the Omnibus Law by the Philippines, where this country has a similar context to Indonesia, namely in terms of investment. The Omnibus Investment Code is a series of regulations that provide comprehensive incentives both fiscal and non-fiscal which are considered by the Philippine government in the context of national development (Citradi, 2020). According to Cabote (2001 the application related to the Onibues Law is as follows: (a). The Omnibus Investments Code (the "Code") mandates the Philippine Board of Investments (BOI) to submit annually, for the President's approval, an Investments Priorities Plan ( "IPP) which lists the preferred area for investment.; and (b). These preferred areas are classified as either pioneer or non-pioneer 1. Persons or entities that engage in the priority areas of investment under the IPP may avail of the incentives provided under the Code upon registration with the BOI2. If the applicant for incentives is a natural person or individual, he must be a citizen of the Philippines. If the applicant is a partnership or any other association, it must be organized under Philippine laws and at least sixty percent $(60 \%)$ of its capital must be owned and held by the Philippine nationals; or in case of a corporation or a cooperative, it is organized under Philippine laws and that at least sixt y per cent (60\%) of the capital stock outstanding and entitled to vote is owned and held by the Philippine nationals and at least sixty per cent $(60 \%)$ of the members of the Board of Directors are citizens of the Philippines.

Furthermore, the application of the omnibus law is available in Turkey or more popularly known as torba kanun, or Turkish omnibus bills (Hazama \& Iba, 2016: 2). According to Hazama \& Iba (2016: 313-333) that there are interesting notes to observe regarding the implementation of omnibus bills in Turkey as follows:. (A). The government used omnibus bills to covertly change existing laws by appending new articles to its own bills under deliberation (i.e. 'appendment'), not by writing proposed law changes into the original bill; and (b). Undercover legislation backfires. The larger the number of current laws changed by an omnibus 
bill, the more likely those changes are to be annulled by the Constitutional Court. In the final analysis, the legislative-efficiency objective behind omnibus bills is undermined by legal errors and deficiencies that result from a lack of parliamentary discussion. Then, in Turkey's current political context, omnibus bill legislation is a harbinger of the executive - legislative relations that would emerge if the current parliamentary system were to be transformed into a Turkish presidential system. This is a project advocated by the President, Recep Tayyip Erdoğan, who has presented no blueprint for such a system except that the president would enjoy greater executive powers. If the Turkish presidential system were to become an executive presidency under a parliamentary system, omnibus bill legislation would closely resemble the manner in which de facto presidential decrees would operate under the parliamentary system. According to Darmawan (2020: 19) and Citradi (2020). Turkey uses the omnibus to make amendments to tax regulations including income tax, VAT, tax spending, pension savings, social security and health insurance, and in 2019 Turkey issued Omnibus Law number 7161 which made several important amendments such as adding currency differences as the basis for VAT. , making the "consumer price ratio" the basis for determining lease price increases, as well as a 70\% tax exemption on wages of private aviation personnel.

Apart from the Philippines and Turkey, several countries that have also implemented the Omnibus Law such as Canada, New Zealand, Australia and Vietnam have been done (Darmawan, 2020: 19; \& Citradi, 2020) as follows: (a) Canada uses the Omnibus Law approach to implementing international trade agreements. Canada modified 23 old laws to comply with Trade Organization (WTO) rules; (b) New Zealand has also implemented the Omnibus Law for taxation as stipulated in the 2019 Taxation Act. This regulation was issued to improve tax arrangements currently in effect within a broad-base and low-rate framework in order to encouraging compliance with tax obligations .; (c) Australia which has also used the omnibus approach. One of the Omnibus Laws in Australia is the Act on Implementation of US FTA which is used to implement the free trade agreement between the United States and Australia; and (d). The omnibus approach is also applied in countries that adhere to civil law such as Vietnam. Omnibus Laws that have been successfully formed by Vietnam include Law Amending and Supplementing a Number of Articles of the Law on ValueAdded Tax, Law on Excise Tax and the Law on Tax Administration. This law amends, adds and revokes several articles contained in the Value Added Tax Law, the Excise Tax Law, and the Tax Administration Law.

Based on these descriptions, it can be concluded that the meaning of omnibus law is a technique in drafting laws that aims to achieve efficiency and effectiveness (Suriadinata, 2019: 115). According to Redi (2020), the omnibus law approach can also be a solution to overlapping regulations in Indonesia, both in horizontal and vertical hierarchical relationships, and the preparation of omnibus law is expensive and not simple because the substance is definitely multi-sector, prepared for super power. Then, the large number of articles of a law using the omnibus law method is unavoidable, especially since it is independent or independent without being bound by other regulations (Redi, 2020). Furthermore, several theories that are known in the existence of a well-known state include the concept of a rule of law and the concept of a welfare state (Darmawan, 2020: 17). In the concept of a rule of law, the state carries out its activities in the corridor of various legal instruments, and the concept of a welfare state, the role of the state becomes dominant in every aspect of people's lives for the realization of social welfare.

According to Dicey (1952) in Jones (1958: 144-150), states that the definition of the concept of a rule of law and a welfare state is as follows: (a). Definition of the concept of a rule of law - in American legal theory; we are more likely to say "rule of law", "rule by law" whose primary purpose is to protect individuals from state power holders. The rule of law is a judicial tradition, a tradition that contains at least three indispensable elements: first, that anyone whose interests will be affected by a court or administrative decision has the right to meaningful "days in court"; second, that the determining officers must be fully independent, free from external direction by political and administrative superiors in the disposition of individual cases and internally free from the influence of personal gain and partisan or popular bias; and third, everyday decisions must be reasoned, justified rationally, in a sense that takes into account both the demands of general principles and the demands of a particular situation; and (b) The understanding of the concept of the welfare state as in nineteenth-century England is as follows: (1) in a decent society, it is inconceivable that the government, or any government official, would have arbitrary power over persons or individual interests; (2) all members of society, both individuals and government officials, must be equally accountable before the law; and (3) effective judicial remedies are more important than abstract 
constitutional declarations in securing individual rights from encroachment by the state. To me these points all seem valid.

The Third Amendment to the 1945 Constitution (UUD) has added to the norms regarding the rule of law in Article 1 paragraph (3) of the Third Amendment to the 1945 Constitution which reads: "The State of Indonesia is a rule of law". This provision is a form of normalization derived from the contents in the explanation of the 1945 Constitution which states "The Indonesian State is based on Law (Rechtsstaat) not based on mere power (Machtsstaat)". By loading it in the norms of the 1945 Constitution, the concept of the rule of law in the explanation of the 1945 Constitution has binding legal force as the highest norm in the national legal system of the Indonesian state (Azhari, 2012: 490). Then, Azhari (2012: 503). Stating that the founders of the country accepted the Rechtsstaat concept, but by changing the socio-economic base to a planned economic system. This is done by accelerating the process of socio-economic decolonization and reconstruction of traditions, so that the Indonesian rule of law has the basis of a welfare state and is rooted in the legal tradition of the Indonesian nation. The aim is not merely to guarantee legal certainty for economic enterprises, but also to provide justice and benefit to the people at large.

Furthermore, the aim of establishing the Republic of Indonesia is basically to improve the welfare of all people without exception. The aim of national development is to increase social welfare, not only for economic growth, but to fulfill various basic social and economic needs of every citizen in order to achieve a minimum standard of living. For example, the articles on welfare in the 1945 Constitution of the Republic of Indonesia (hereinafter referred to as the 1945 Constitution of the Republic of Indonesia) and its amendments are more numerous, when compared to the constitutions of other countries aimed at welfare such as Norway, Japan, America and Malaysia which have the human development index is relatively high. Indonesia has 14 welfare articles in the 1945 Constitution but does not have the power to form a prosperous society when compared to the constitutions of other countries with welfare objectives such as Norway, Japan, America and Malaysia which have relatively high human development indexes. Norway only includes 3 articles in its constitution Article 110,110a and Article 110b2 but is able to achieve an almost perfect HDI. Likewise with Japan which only includes 1 article on welfare in the constitution of the Japanese state (Elviandri et.al. 2019: 253).

Thus, the State of Indonesia is often referred to as a country that carries the idea of a welfare state, this is because in the preamble to the 1945 Republic of Indonesia there is one of the objectives of the state which expresses the idea of a welfare state. In this case, Pancasila as a philosophische grondslag is stated in the Preamble of the 1945 Indonesian Constitution, which means that Pancasila is positioned as a source of constitutional law in Indonesia, is an inspiration for the formation of the rule of law in Indonesia (Alimuddin, 2013: 4). Therefore, Indonesia is a legal state that carries the idea of a welfare state, so the concept of Omnibus Law must be in accordance with the corridors of law, so the formation and implementation of legislative policies must be based on the values that develop in society to achieve the goals of a state in accordance with Pancasila and the Basic Law. 1945. In theory of legislation in Indonesia, the position of the Law from the concept of the Omnibus Law has not been regulated so that problems will arise related to its position and this must be given legitimacy by revising Law No.12 of 2011 concerning the Formation of Legislation (Darmawan, 2020: 17 ). Thus, it is necessary to make extra careful harmonization efforts not only with laws that will be repealed with an omnibus lawn and a Perppu which can be the best form of omnibus law option (Redi, 2020).

\section{Historical Review of Omnibus Law / Simplification of Legislation in Indonesia}

According to Hamid. (2020: 258), in Indonesia, the Minister of Agrarian and Spatial Planning / Head of the National Land Agency (BPN / ATR) of the Republic of Indonesia, Sofyan Djalil, once touched on the concept of omnibus law related to overlapping regulations, especially related to investment. For example, when there is a proposal to improve regulations in the forestry sector, what must be revised is Law no. 41/1999 on Forestry. However, there are still obstacles in other regulations, such as Law no. 32/2009 concerning Environmental Protection and Management-PPLH or Law no. 5/1960 concerning Basic Agrarian Principles (Hamid. 2020: 258.). Then, the term Omnibus law became known in Indonesia since the President of the Republic of Indonesia, Joko Widodo delivered his first speech at his inauguration on October 20, 2019, which identified at least 74 laws that were affected by the omnibus law (Idris, 2020). 
The concept of the omnibus law continues to roll out and develops rapidly and has become a topic of discussion among law-forming institutions other than the Government, namely the People's Representative Council of the Republic of Indonesia and the Regional Representative Council of the Republic of Indonesia. In the 2020-2024 National Legislation Program, there are 3 (three) proposals of the omnibus law concept out of 248 bills, namely the Job Creation Bill; Draft Law on Development and Strengthening of the Financial Sector; and the Bill on Taxation Provisions and Facilities for Economic Engagement (Azanella, 2019 in Anggraeni \& Rachman, 2020: 180). The various meanings of omnibus can be understood as statutory regulations designed to target a large problem that can be repealed or change several laws at once to become simple. As has been released and known through research and websites, the number of laws and regulations in Indonesia has reached the hyper-regulatory or obesity stage, for example on the regulation.go.id site, it is known that there are 1687 laws, 180 PP in lieu of laws, 4558 PP, Presidential Decree 2008, Permen 14722, PP 3758 PP, PP 15965 so that the concept of omnibus law becomes a concern and offers a strategy for simplifying regulations in Indonesia (Anggraeni \& Rachman, 2020:180).

According to Setiadi (2018: 323), the quantity or number of laws and regulations in the business sector is not proportional, even tends to be over-regulated .. and almost every agency whose duties and functions are related to the sector try to form regulations and in the formation of these regulations do not coordinate with each other and instead mutually prioritizing their respective sectors plus the formers of regulations cannot / want to realize that the formation of laws and regulations is actually a process of unifying or harmonizing various interests.Then, the number of laws and regulations in Indonesia, in the database of the Directorate General of Legislation, Ministry of Law and human rights. In detail, the number of laws and regulations from 1945 to 2018 are: (1) 10 Basic Laws (UUD); (2) Decree of the People's Consultative Assembly (MPR) as many as 5; (3) Laws (UU) as many as 1902; (4) Government Regulations in Lieu of Law (PERPPU), 172; (5) Government Regulations (PP) as many as 4836; (6) Presidential Regulation (PERPRES), 1882; (7) 24 Supreme Audit Agency (BPK) regulations; (8) Bank Indonesia Regulations (PBI), as many as 123; (9) Ministerial Regulations (PERMEN), 12,829; (10) 3652 Non-Ministerial Government Institution Regulations (LPNK); (11) Regional Regulations (PERDA) of 15,205; 12) Financial Services Authority (POJK) as many as 263 regulations. From the data on these laws and regulations, there are 40,903 laws and regulations in total. (Setiadi, 2018: 323).

Observing this condition, the simplification or simplification of statutory regulations is carried out in order to reduce the existing laws and regulations so that they are proportional to the number, and the alternative is to reduce the number of unnecessary and / or problematic laws and regulations, ensure effectiveness and prevent overlapping laws and regulations and cutting lengthy, lengthy procedures to minimize or reduce excessive costs (Setiadi, 2018: 326-327). According to www.regulatoryreform. com dated April 1, 2017 in Setiadi (2018: 327) that several countries have implemented programs of simplification or trimming of laws and regulations or regulations, for example, South Korea, Mexico, Moldova, Ukraine as follows:

Table 1: Best Practices of Regulatory Simplification

\begin{tabular}{|l|l|l|l|l|l|}
\hline No & $\begin{array}{l}\text { Countries/ Duration } \\
\text { of carrying out the } \\
\text { simplification } \\
\text { program }\end{array}$ & Target & $\begin{array}{l}\text { Before } \\
\text { Simplificatio } \\
\text { n }\end{array}$ & $\begin{array}{l}\text { Revoked } \\
\%\end{array}$ & Simplification \\
\hline 1 & Korea (11 months) & Regulations & 11.125 & $48.8 \%$ & $21.7 \%$ \\
\hline 2 & Mexico (5 years) & Formalities & 2.038 & $54.1 \%$ & $51.2 \%$ \\
\hline 3 & Moldova (16 weeks) & $\begin{array}{l}\text {-Regulations } \\
\text {-Fee Based } \\
\text { Permits }\end{array}$ & $\begin{array}{l}400 \\
4.130\end{array}$ & $\begin{array}{l}64.5 \% \\
12.5 \%\end{array}$ \\
\hline 4 & Ukraine (12 weeks) & Regulations & 15.000 & $46.7 \%$ & $43.3 \%$ \\
\hline
\end{tabular}

Source: Processed from www.regulatoryreform in Setiadi (2018: 327) 
Based on table 1, it can be interpreted that the 4 (four) countries have successfully implemented a program of simplification or trimming of laws and regulations or regulations, and the result is an increase in the ease of doing business or doing business and have succeeded in attracting more investment. Efforts to simulate these regulations run in accordance with the norms, processes and applicable legal provisions so that they can be well accepted by the wider community in each of these countries, Then, the omnibus law method is not completely new to Indonesia, apart from the term, the substance of the omnibus law has already been used in legislation (Redi, 2020). Historically, the application of Omnibus Law in Indonesia means simplification or simplification of laws and regulations towards synchronization and harmonization. has been done as follows:

\section{Table 2: Historical Overview of the Omnibus Law / Simplification of Legislation in Indonesia}

\begin{tabular}{|c|c|c|}
\hline No & Year & $\begin{array}{l}\text { Application of the Omnibus Law / Simplification of Legislation in } \\
\text { Indonesia }\end{array}$ \\
\hline 1 & 1983 & $\begin{array}{l}\text { Regulatory Reform has already been carried out in Indonesia. These efforts are } \\
\text { made in certain sectors or in response to certain situations. In 1983, for } \\
\text { example, when there was an over-regulation of the banking sector which } \\
\text { resulted in a stagnant condition and the loss of banking initiatives, Bank } \\
\text { Indonesia (BI) carried out banking modernization in accordance with the } \\
\text { demands of society, the business world and economic life during that period. } \\
\text { Deregulation begins with the elimination of credit ceilings; banks are free to set } \\
\text { interest rates for loans, savings and deposits; as well as stopping the provision } \\
\text { of Bank Indonesia Liquidity Credit (KLBI) to all banks, except for certain types } \\
\text { of credit related to cooperative development and exports. The initial stage of } \\
\text { deregulation succeeded in fostering a competitive climate between banks. The } \\
\text { issuance of the banking deregulation package on June } 1 \text {, 1983 (Pakjun 1983) } \\
\text { was the starting point for banking liberalization. Through this package, the } \\
\text { government has given freedom to banks to determine their own interest rates on } \\
\text { deposits and loans. Banks also have the authority to remove ceilings in lending, } \\
\text { reduce Bank Indonesia (BI) liquidity credit, and BI introduced monetary } \\
\text { instruments of Bank Indonesia Certificates or } \\
\text { (wartakota.tribunnews.com/2015/03/01). }\end{array}$ \\
\hline 2 & 1988 & $\begin{array}{l}\text { The Policy Package for } 27 \text { October } 1988 \text { was put into effect, among others, } \\
\text { with the aim of: (a) Increasing Community Fund Collection. The government } \\
\text { policy together with Bank Indonesia in order to increase fundraising contained } \\
\text { in the opportunity to establish new banks, open bank branch offices and Non- } \\
\text { Bank Financial Institutions (LKBB), and provide freedom to make savings and } \\
\text { deposits (Rahardja, 1997: 99); (b) Encouraging Non-Oil and Gas Exports. The } \\
\text { policy to increase non-oil and gas exports is carried out by expanding and } \\
\text { improving services to banks and LKBB. In realizing this goal, the Pakto } 1988 \\
\text { provided facilities for national banking institutions to become foreign exchange } \\
\text { banks, the establishment of joint venture banks, and the opening of foreign bank } \\
\text { sub-branches (Djiwandono, et al., 2006: } 45-46 \text { ); (c) Increasing the Efficiency of } \\
\text { Banks and LKBB. Increasing the efficiency of banking and financial } \\
\text { institutions and LKBB is done by creating a healthy competitive climate. This } \\
\text { can be achieved through the placement of BUMN and BUMD funds in private } \\
\text { banks and LKBB as well as expanding the operational network of banks and } \\
\text { branch offices (Budianto, 2004: } 27 \text { ); (d) Increasing the principle of prudence in } \\
\text { banking institutions and LKBB by imposing a maximum credit limit (LLL) for } \\
\text { both individual customers, group customers, as well as shareholders and leaders } \\
\text { including managers. LLL for individual and group customers is set at } 20 \% \text { and } \\
50 \% \text { of the bank's own capital, respectively. Meanwhile, for shareholders or } \\
\text { companies owning it is set at } 25 \% \text {. Members of the board of commissioners are } \\
\text { not individual shareholders or companies whose maximum credit limit is } 5 \% \text { of }\end{array}$ \\
\hline
\end{tabular}




\begin{tabular}{|c|c|c|}
\hline & & $\begin{array}{l}\text { the bank's own capital. The maximum limit for providing credit for the entire } \\
\text { group is limited to 15\% (Djiwandono, et al., 2006: 47); (e) Supporting Capital } \\
\text { Market Development (Winarti \& Rinardi, 2020,32,). }\end{array}$ \\
\hline 3 & 2003 & $\begin{array}{l}\text { The October } 1993 \text { Package (Pakto 1993) was intended to attract investors to } \\
\text { invest in Indonesia, and the government issued a deregulation package. The } \\
1993 \text { Pakto regulates five business fields, namely: (a) Export Sector, (b) } \\
\text { Foreign Investment Sector, (c) Licensing for Investment, (4) Health Sector, and } \\
\text { (5) Simplification of Environmental Impact Analysis Procedures or AMDAL } \\
\text { (Diani Sadiawati, et al. National Strategy for Regulatory Reform: Realizing } \\
\text { Orderly and Simple Regulations, Ministry of National Planning and } \\
\text { Development / Bappenas, Jakarta, 2015: 28-29) }\end{array}$ \\
\hline 4 & 2016 & 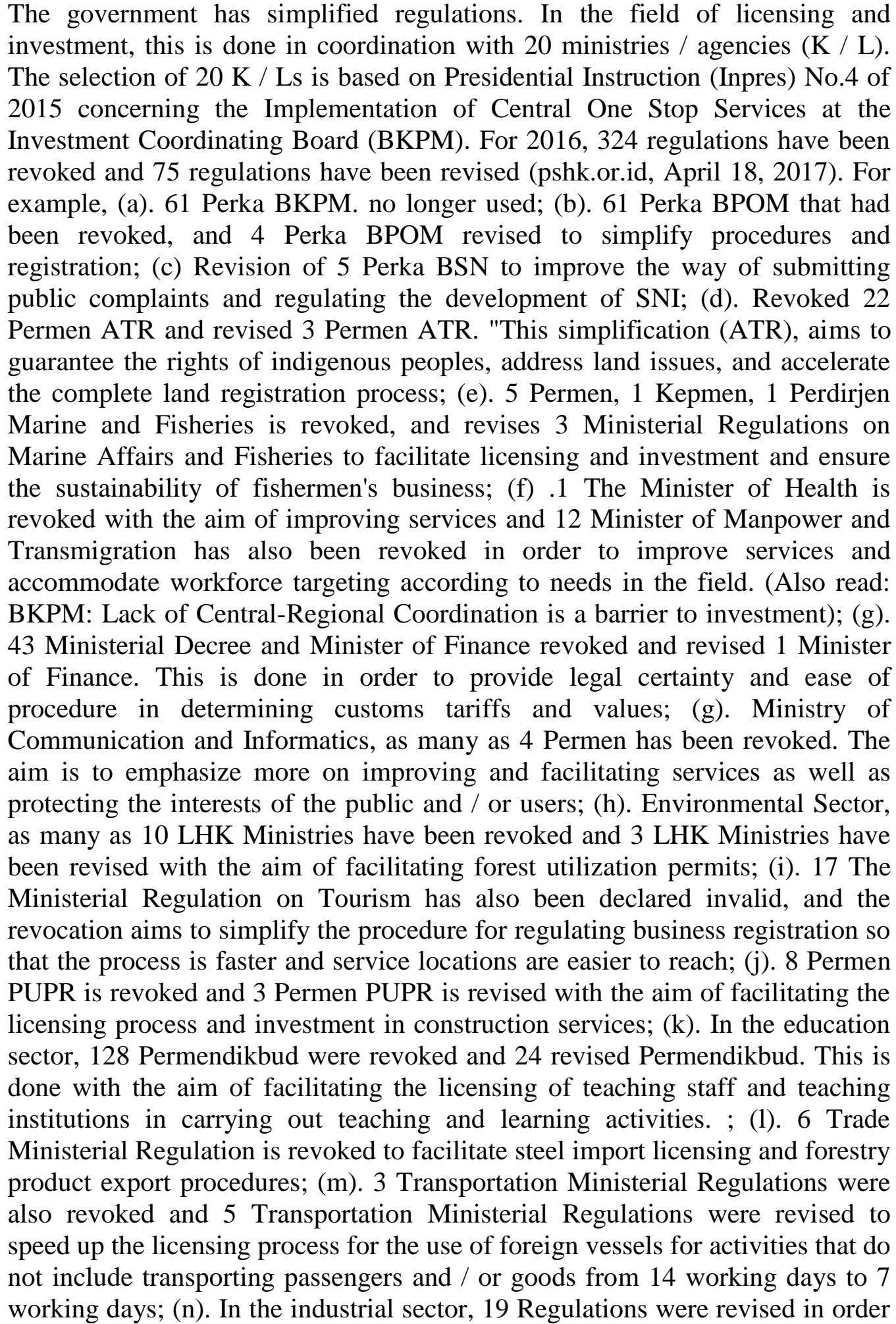 \\
\hline
\end{tabular}




\begin{tabular}{|c|c|c|}
\hline & & $\begin{array}{l}\text { to facilitate the import of similar goods which are actually not subject to the } \\
\text { obligation to meet SNI standards; (o). } 2 \text { The Ministerial Regulation in the } \\
\text { agricultural sector is revoked and revises } 1 \text { Minister of Agriculture concerning } \\
\text { the import of meat, the import of cattle, and guidelines for licensing of } \\
\text { plantation businesses; (p) .2 SOE Ministerial Regulation concerning procedures } \\
\text { for the appointment of directors, commissioners and supervisors of BUMN; (q). } \\
\text { The plan to revise the Minister of Energy and Mineral Resources regarding } \\
\text { business licenses for mineral and coal mining as well as oil and gas, as well as } \\
\text { plans to issue a Ministerial Regulation on Law and Human Rights regarding } \\
\text { applications for registration of marks (s). In addition to the cancellation and } \\
\text { revision of a number of regulations, several Ministries have also simplified } \\
\text { regulations such as the Coordinating Ministry for Economic Affairs (Menko), } \\
\text { which has carried out } 204 \text { deregulation through a number of policy packages } \\
\text { including revocation, revision, and formation of new regulations; (t) The } \\
\text { Ministry of Home Affairs also canceled 3,143 regulations consisting of } \\
\text { Regulations and Decrees of the Minister of Home Affairs as well as Regional } \\
\text { Regulations that contradict higher regulations, public interests, and / or morals } \\
\text { and impede investment. (Setiadi, 2018: } 328 \text { ). }\end{array}$ \\
\hline 5 & 2018 & $\begin{array}{l}\text { Currently, in the context of ease of doing business, Government Regulation } \\
\text { (PP) Number } 24 \text { of } 2018 \text { concerning Electronically Integrated Business } \\
\text { Licensing Services has been promulgated on June 21, 2018, which is one of the } \\
\text { simplifications of legislation in the business ease sector, because all licensing } \\
\text { procedures are integrated and carried out in an integrated manner. electronic In } \\
\text { this Government Regulation, it is stated that Electronically Integrated Business } \\
\text { License (OSS) is a Business License issued by the OSS Institution for and on } \\
\text { behalf of the Minister, Head of Institution, Governor or Regent / Mayor to } \\
\text { business actors through an integrated electronic system. Based on this } \\
\text { provision, it can be said that even though the granting of licenses is carried out } \\
\text { in an integrated manner, the authority to grant permits is still based on the laws } \\
\text { and regulations and the authority of the sector and region. A very important } \\
\text { provision in this PP is the order to carry out Sector Undertaking Licensing } \\
\text { Reform. The implementation of this reform includes business licensing in the } \\
\text { following sectors: (a). electricity; (b). agriculture; (c). environmental and } \\
\text { forestry; (d). public works and public housing; (e). marine and fisheries; (f). } \\
\text { health; (g). medicine and food; (h). industry; (i). trading; (j). transportation; (k). } \\
\text { communication and informatics; (l). finance; (m). tourism; (n). education and } \\
\text { culture; (o). higher education; (p). religion and religion; (q). employment; (r). } \\
\text { police; (s). cooperatives and micro, small, medium enterprises; and T). nuclear. } \\
\text { (Setiadi, 2018: } 328 \text { ). }\end{array}$ \\
\hline
\end{tabular}

\section{Source: Processed from various sources}

Based on table 2, Indonesia has actually implemented 4 (four) times the Omnibus Law or the implication of regulations and legislation as a stimulus to increase economic growth and the investment climate. Deregulation or simplification of laws and regulations did not face great challenges from academics or the wider community because when viewed from a relatively limited spectrum and focused on the fields of economy, investment, government administration, health, land, maritime, communication and informatics, environment life, public works and public housing (PUPR), transportation, trade, industry, agriculture, education, and State Owned Enterprises (BUMN).

\section{Analysis of the Omnibus Law / Job Creation Act. (OL / JCA) after being ratified by the Legislative (People's Representative Council)}

Before and after the ratification, there was a large wave of protests against and against the Omnibus Law (OL / JCA). Prior to the ratification period, during the discussion period, various circles of society] stated strongly against the OL / JCA Bill because the technique of drafting laws through the OL /JCA approach 
was only applied in the Indonesian legal system, this new rule was considered detrimental to workers, potentially violating rights. human rights, has a negative impact on the environment, and the process of composing it is distant from the public. Public involvement and participation in the legislative process, including processes in the executive area, is guaranteed by Law (UU) No. 12 of 2011 concerning the Establishment of Legislation. Article 96 of Law No.12 of 2011 emphasizes that draft laws and regulations must be easily accessible to the public. In other words, community involvement becomes a space for a wide open dialogue between policy makers / laws and regulations and the community. As a result, the substance of the OL /JCA Bill and has been passed by the Indonesian Parliament, the OL / JCA Bill has invited a lot of controversy.This condition occurs because the OL / JCA discussion and approval tends to ignore the public's will. In fact, law is basically the public will, so it is not just law in the sense of law in books., There is a careful compromise between written law as a need for the legal community for the creation of legal certainty (positivism law) and living law as a form of appreciation for the importance of the role of society in legal formation and legal orientation. Then, law is social-actual norms that govern all aspects and cannot be let go of social conditions, because order in society is based on social recognition of law and not because of its official application by the state. Thus, the law must be in line with the living law that will apply in society

Then, after the legalization in various provinces in Indonesia, as well as thousands of demonstrators were arrested, injured, detained, and there was violence against journalists to paramedics who carry out tasks as per law and humanitarian calls. The irony is again, at the same time four versions of the draft Job Creation law have appeared. The draft version is 905 pages each (circulating October 5); 1,052 pages (circulating October 9); 1,035 pages thick (circulated October 12 morning); and 812 pages thick (circulating October 12 evening). The 812 page document is recognized as an official and final draft (.Amali, 2020). OL/JCA is a new regulation to attract investment into the country and will have an impact on the revision of 79 laws and 1,244 articles which are considered to hinder investment during the second term of the presidency of the President of the Republic of Indonesia, Joko Widodo). In this context, OL / JCA can be interpreted as government political policy in the economic realm which includes the following: Spatial suitability, Environmental Approval, Building Approval with the application of standard function-worthy certificates, Application of risk-based licensing, MSME and Cooperatives, Research and Innovation, Follow-up on WTO decisions, Structuring business licensing authority (central and regional), investment management institutions, land procurement and land banks, investment requirements, halal product guarantee certification, revocation of regional regulations, ease of doing business, and restructuring of sanctions by applying ultimum remedium (Iwan; \& Djailani i, 2020).

However, the application of the omnibus law is considered likely to have the opportunity to add to a series of new problems in the Indonesian legal system. The OL/JCA discussion contradicts Law No.12 of 2011 concerning the Formation of Legislative Regulations as updated by Law No.15 of 2019 does not regulate the omnibus law mechanism because the omnibus law is not commonly applied in Indonesia because it uses the legal system civil law. Then, the discussion process until its approval tends to be hasty and closed and ignores the principles of Good Corporate Governance (GCG) which consist of: Information Disclosure, Accountability, Responsibility, Independency, and Fairness (Equality. Thus, OL /JCA. tends to produce policies that are discriminatory and violate the rights of citizens guaranteed by the constitution.

As a rule of law, the 1945 Constitution of the Unitary State of the Republic of Indonesia (NKRI) article 1 paragraph (3) states that the State of Indonesia is a constitutional state. Chapter X, article 27 paragraph (1), which states that all citizens are equal before the law and the government is obliged to uphold the law and government without exception. In article 28 paragraph (5) which states that in order to uphold and protect human rights in accordance with the principles of a democratic rule of law, the implementation of human rights is guaranteed, regulated and stated in statutory regulations. A state based on law is characterized by several principles including that all actions or actions of a person, whether individual or group, people or government, must be based on legal provisions and statutory regulations that existed before the act or action was carried out or based on applicable regulations. Legislation must use legal principles as richtlijnen guidelines for the formation of positiveringsarbied law. Legislation needs to examine the rationale for these legal principles, formulate them and apply them in the formation of laws. (Notohamidjojo in Suparto, 1975: 50). Therefore, it is recommended that OL/JCA which aims to encourage accelerated economic growth should be perfected and follow the legal system in Indonesia in an effort to simplify or simplify regulatory obesity in Indonesia. In this case, President Joko Widodo can issue a Government Regulation in Lieu of Law 
(Perppu). Perppu is the Legislation which is stipulated by the President in matters of compelling urgency as set out in the 1945 Constitution of the Republic of Indonesia Article 22 paragraph (1) even though the Indonesian Parliament has ratified it. Then, there is a very basic principle or basis for thinking in Indonesian legislation that can deflate the 'supernatural powers' of the omnibus law method through the lex posterior derogat legi priori principle, meaning that the law passed later will still be able to set aside the omnibus law if the content is different ( Redi, 2020).

\section{Conclusions \& Recommendations}

The substance of OL/JCA is designed in such a way with the aim that changes in the economic structure can be realized in order to move all sectors in order to encourage economic growth through job creation, increased investment and productivity followed by increased wages. Then, the direction of OL/JCA is simplification or harmonization of regulations and licensing so that it can increase investment and quality work creation as well as sustainable worker welfare and empowerment of MSMEs. . The process and discussion of OL/JCA contradicts Law (UU) No.12 of 2011 concerning the Formation of Laws and Regulations as updated by Law No.15 of 2019 does not regulate the omnibus law mechanism because the omnibus law is not commonly applied in Indonesia because it uses civil law legal system. However, the process and discussion of OL/JCA tends to ignore community involvement as stipulated in the 1945 Constitution of the Unitary State of the Republic of Indonesia (NKRI) article 1 paragraph (3), article 27 paragraph (1), and article 28 paragraph (5). In this case, Pancasila as a philosophische grondslag is stated in the Preamble of the 1945 Indonesian Constitution which means that Pancasila is positioned as a source of constitutional law in Indonesia, is an inspiration for the formation of the rule of law in Indonesia.

Therefore, it is recommended that OL/JCA which aims to encourage accelerated economic growth should be perfected and follow the legal system in Indonesia in an effort to simplify or simplify regulatory obesity in Indonesia. In this case, OL/JCA is a law that must be based on social-actual norms that regulate all aspects so that it is not allowed to be released with social conditions, because order in society is based on social recognition of the law and not because of its official application by the state. This means that the law must be in line with the living law that will apply in society. Thus, President Joko Widodo can issue a Government Regulation in Lieu of Law (Perppu). Perppu is the Laws and Regulations stipulated by the President in matters of compelling urgency as set out in the 1945 Constitution of the Republic of Indonesia Article 22 paragraph (1).

\section{References}

[1.] Alawamleh, Mohammad; Ismail1,Loiy Bani; Aqeel, Diana;and Alawamleh,Kamal Jamal .(2019). The bilateral relationship between human capital investment and innovation in Jordan. Journal of Innovation and Entrepreneurship. https://doi.org/10.1186/s13731-019-0101-3.

[2.] Alimuddin.(2015).KONSEP NEGARA HUKUM YANG SEJAHTERA DALAM UNDANGUNDANG DASAR 1945. https://badilag.mahkamahagung.go.id/ artikel /publikasi/artikel/konsepnegara-hukum-yang-sejahtera-dalam-uud-1945-oleh-alimuddin-shi-mh-17 . Accessed on October $25,2020$.

[3.] Amali, Zakki. (2020). "Kronologi Omnibus Law Disahkan hingga Jokowi Terima UU Cipta Kerja", https://tirto.id/kronologi-omnibus-law-disahkan-hingga-jokowi-terima-uu-cipta-kerjaf5YM. Accessed on October 21, 2020

[4.] Anggraeni, Ricca; \& Rachman, Cipta Indra Lestari.(2020) Omnibus Law in Indonesia: Is That the Right Strategy? Advances in Economics, Business and Management Research, volume 140 International Conference on Law, Economics and Health (ICLEH 2020).https://www.researchgate.net/publication/341512 891 _Omnibus_Law_in_Indonesia_Is_That_the_Right_Strategy/link/5ec524fd299bf1c09acc3dc0/down load.

[5.] Azhar,Muhamad.(2019). Omnibus Law sebagai Solusi Hiperregulasi Menuju Sonkronisasi Peraturan Per-Undang-undangan di Indonesia. Administrative Law and Governance Journal (eISSN 2621-2781) . DOI: https://doi.org/10.14710/alj.v2i1.170-178

[6.] Azhari, Aidul Fitriciada. (2012). Negara Hukum Indonesia: Dekolonisasi dan Rekonstruksi Tradisi. Jurnal Hukum IUS QUIA IUSTUM NO. 4 VOL. 19 OKTOBER 2012: 489 - 505. https://media.neliti.com/media/publications/80799-ID-negara-hukum-indonesia-dekolonisasidan.pdf 
[7.] Babbie,Earl. (1986) The Practice of Social Research, fourth edition (California, Belmont: Wadsworth Publishing Co.

[8.] Bierscbach, Briana. (2017). 'Everything You Need to Know About Omnibus Bills, and Why They're So Popular at The Minnesota Legislature' (Minnpost, March 31, 2017) https://www.minnpost.com/politics-policy/2017/03/everything-you-need-know-about-omnibusbills-and-why-theyre-so-popular-minne Accessed on October 22, 2020

[9.] Busroh, Firman Freaddy.(2017). KONSEPTUALISASI OMNIBUS LAW DALAM MENYELESAIKAN PERMASALAHAN REGULASI PERTANAHAN. ARENA HUKUM

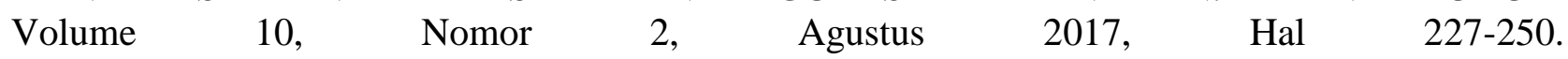
https://arenahukum.ub.ac.id/index.php/arena/article/viewFile/327/269 Accessed on October 22, 2020

[10.] Cabote, .Regulus E (2001).Philippines: Investment Incentives Under The Omnibus Investment Code Of The Philippines. 17 January 2001. https://www.mondaq.com/investmentstrategy/9714/investment-incentives-under-the-omnibus-investment-code-of-the-philippines. Accessed on October 22, 2020.

[11.] Citradi, Tirta.(2020). Tak Cuma di RI, Omnibus Law Banyak Dipakai Negara Lain NEWS -, CNBC Indonesia 21 January 2020. https://www.cnbcindonesia.com/news/20200121152155-4131621/tak-cuma-di-ri-omnibus-law-banyak-dipakai-negara-lain . Accessed on October 22, 2020.

[12.] Darmawan, Agus. (2020). POLITIK HUKUM OMNIBUS LAW DALAM KONTEKS PEMBANGUNAN EKONOMI INDONESIA. Indonesian Journal of Law and Policy Studies | Volume 1 No. 1 Mei 2020. file:///C:/Users/user/Downloads/2655-6395-1-PB.pdf .Accessed on October 22, 2020

[13.] Daud Silalahi \& Lawencon Associates "DSLA",15 April 2020). “Omnibus Law Cipta Lapangan Kerja: Pengertian, Tujuan, dan Manfaat”. https://www.dslalawfirm.com/omnibus-law . Accessed on October 21, 2020

[14.] Dodek,Adam M. (2017). Omnibus Bills: Constitutional Constraints and Legislative Liberations.Ottawa Law Review, Vol. 48, No. 1, 2017 https://papers.ssrn.com/sol3/ Data_Integrity_Notice.cfm?abid=2889773. Accessed on October 22, 2020

[15.] Dror, Yahezkel, Law and Social Change, dalam Vilhelm Aubert, Sociology of Law, cet. I, (Australia: Penguin Books, 1969)

[16.] Elviandri; Dimyati, Khuzdaifah; dan Absori . (2019). QUO VADIS NEGARA KESEJAHTERAAN: MENEGUHKAN IDEOLOGI WELFARE STATE NEGARA HUKUM KESEJAHTERAAN INDONESIA. https://www.researchgate .net/publication/338887414_QUO_VADIS_NEGARA_KESEJAHTERAAN_MENEGUHKAN_I DEOLOGI_WELFARE_STATE_NEGARA_HUKUM_KESEJAHTERAAN_INDONESIA/link/5 e3182c992851c7f7f0a572f/download. Accessed on October 21, 2020

[17.] Fuadi, Munir Fuadi. (2013). Teori-Teori Besar (Grand Theory) Dalam Hukum, (Jakarta: Kencana Prennamdeia Group),

[18.] Garner,Bryan A., .(1999). Black’s LawDictionary, seventh edition St.Paul, MN : West Group,

[19.] Hamid, Adnan. (2020). Analysis of the Importance of Omnibus Law "Cipta Kerja" In Indonesia. International Journal of Scientific Research and Management (IJSRM) ||Volume||08||Issue||08||Pages||LLA-2020-236-250||2020|| Website: www.ijsrm.in ISSN (e): 23213418 DOI: $10.18535 / \mathrm{ijsrm} / \mathrm{v} 8 \mathrm{i08} .1 \mathrm{la0} 1$

[20.] Hamid, Usman. (2020) "RUU Cipta Kerja Ancam Hak Asasi Manusia" dalam amnesty.id/ August 19, 2020. https://www.amnesty.id/ruu-cipta-kerja-ancam-hak-asasi-manusia/.Accessed on October 21, 2020.

[21.] Hazama, Y., \& Iba, Ş. (2016). Legislative agenda setting by a delegative democracy: omnibus bills in the Turkish parliamentary system. Turkish Studies, 18(2), 313-333. doi:10.1080/14683849.2016.1261022

[22.] Huijbers, Theo . (1998). Filsafat Hukum dalam Lintasan Sejarah, cet. V, (Yogyakarta: Kanisius)

[23.] Idris, Muhammad. (2020). Masih Bingung Apa Itu Omnibus Law? https://money.kompas.com/read/2020/02/18/160300026/masih-bingung-apa-itu-omnibuslaw?page=all. Accessed on October 22, 2020.

[24.] Ihsan, Fahrul. 2008. Ekonomi Pancasila : Gagasan Dan Kemungkinan, Pustaka LP3ES, Jakarta 
[25.] Jones, Harry W. (1958). The Rule of Law and the Welfare State Columbia Law Review Vol. 58, No. 2 (Feb., 1958), pp. 143-156 (14 pages) Published By: Columbia Law Review Association, Inc. DOI: 10.2307/1119825 https://www.jstor.org/stable/1119825. Accessed on October 21, 2020

[26.] Kirchhoffa, Denis, and Tsuji, Leonard J.S. (2014). Reading between the lines of the 'Responsible Resource Development' rhetoric: the use of omnibus bills to 'streamline' Canadian environmental legislation. Impact Assessment and Project Appraisal, 2014 Vol. 32, No. 2, 108-120, http://dx.doi.org/10.1080/14615517.2014.894673. Accessed on October 21, 2020

[27.] Kompas.com 06 Okt. 2020. "Isi Lengkap RUU Cipta Kerja Bisa Diunduh di Sini",. https://money.kompas.com/read/2020/10/06/080241226/isi-lengkap-ruu-cipta-kerja-bisa-diunduhdi-sini?page=all . Accessed on October 21, 2020.

[28.] Krutz, Glen. S. (2001). Tactical Maneuvering on Omnibus Bills in Congress. American Journal of Political Science, 45(1), 210. doi:10.2307/2669368. https://www.sci-hub.ren/10.2307/2669368 ..Accessed on October 21, 2020

[29.] liputan6.com. 05 Feb 2020 "Jumlah Lapangan Kerja Bertambah Meski Ekonomi Indonesia Melambat" https://www.liputan6.com/bisnis/read/4171857/jumlah-lapangan-kerja-bertambahmeski-ekonomi-indonesia-melambat .Accessed on October 21, 2020.

[30.] Meilani, Hilma .(2019). "HAMBATAN DALAM MENINGKATKAN INVESTASI ASING DI INDONESIA DAN SOLUSINYA". BIDANG EKONOMI DAN KEBIJAKAN PUBLIK KAJIAN SINGKAT TERHADAP ISU AKTUAL DAN STRATEGIS Vol. XI, No.19/I/Puslit/Oktober/2019. Pusat Penelitian BIDANG EKONOMI DAN KEBIJAKAN PUBLIK Badan Keahlian DPR RI Gd. Nusantara I Lt. 2 Jl. Jend. Gatot Subroto Jakarta Pusat infosingkat@gmail.com

[31.] Nugraha, Ricky Mohammad. (2020). Kadin Defends Birth of Job Creation Law; Cites Long Term Competitive Edge. 19 October 2020 https://en.tempo.co/read/1397305/kadin-defends-birth-of-jobcreation-law-cites-long-term-competitive-edge . Accessed on October 21, 2020.

[32.] Nightingale, Robert L. (2016). How To Trim a Christmas Tree: Beyond Severability and Inseverability for Omnibus Statutes, 125 Yale L.J.

[33.] "Omnibus Law / UU Cipta Kerja." yang telah disahkan menjadi Undang-Undang (UU) oleh Dewan Perwakilan Rakyat Republik Indonesia (DPR RI), Senin (5 Oktober 2020)

[34.] pshk.or.id ( April 18, 2017.).Mengintip Simplifikasi Regulasi di Tahun 2016. https://pshk.or.id/berita/mengintip-simplifikasi-regulasi-di-tahun-2016/ . Accessed on October 21, 2020.

[35.] Redi, Ahmad. (2020). Mengutip literatur The Library of Parliament and the House of Commons Procedure and Practice handbook."Terkait pengaturan railway," https://www.hukumonline.com/berita/baca/lt5e2c1e4de971a/menelusuri-asal-usul-konsepomnibus-law?page=2. Accessed on October 23, 2020.

[36.] Sadiawati,Diani et al. (2015). Strategi Nasional Reformasi Regulasi: Mewujudkan Regulasi yang Tertib dan Sederhana, Kementerian Perencanaan dan Pembangunan Nasional/ Bappenas, Jakarta

[37.] Setiadi, Wicipto. 92018). Simplifikasi Peraturan Perundang-Undangan dalam Rangka Mendukung Kemudahan Berusaha (Simplification of Regulations in Order to Support Ease of Doing Business) Jurnal Rechtsvinding. Volume 7, Nomor 3, Desember 2018 https://rechtsvinding.bphn.go.id/artikel/artikel\%201.PDF . Accessed on October 24, 2020

[38.] Supriyatna, Iwan ;\& Djailani, Mohammad Fadil .(2020). 15 Poin Substansi RUU Omnibus Law Telah Disepakati. | https://www.suara.com/bisnis/2020/ 09/24/ 142929/15-poin-substansi-ruuomnibus-law-telah-disepakati . Accessed on October 25, 2020.

[39.] Suriadinata, Vincent. (2019). PENYUSUNAN UNDANG-UNDANG DI BIDANG INVESTASI: KAJIAN PEMBENTUKAN OMNIBUS LAW DI INDONESIA. Refleksi Hukum: Jurnal Ilmu Hukum, 4(1), 115-132. https://doi.org/https://doi.org/10.24246/jrh.2019.v4.i1.p115-132.

[40.] The Asia Securities Industry and Financial Markets Association - ASIFMA. (2019). China's Capital Markets The Pace of Change Accelerates June 2019 https://www.asifma.org/wpcontent/uploads/2019/06/final-english-china-capital-markets-report-2019.pdf Accessed on October 21, 2020. 
[41.] The Socioeconomic Report - SER. Facilitating TRANSITION, Implementing CHANGE (2017). https://www.neda.gov.ph/wp-content/uploads/2018/03/SER-2017_as-of-June-2018.pdf . Accessed on October 21, 2020.

[42.] Undang-Undang Dasar (UUD) Tahun 1945.

[43.] Undang-Undang (UU) No. 12 Tahun 2011 tentang Pembentukan Peraturan Perundang-undangan.

[44.] Undang-undang (UU) Nomor 15 Tahun 2019 tentang Perubahan atas Undang-Undang Nomor 12 Tahun 2011 Tentang Pembentukan Peraturan Perundang-Undangan

[45.] Wartakota.tribunnews.com (2015/03/01). Belajar dari Krisis Ekonomi 1997, https://wartakota.tribunnews.com/2015/03/01/belajar-dari-krisis-ekonomi-1997. Accessed on October 24, 2020.

[46.] Winarti, W; \& Rinardi, Haryono. (2020). Paket Kebijakan Deregulasi 27 Oktober 1988 (Pakto 1988): Pengaruhnya Terhadap Liberalisasi Perbankan Indonesia Periode 1988-1993 Historiografi, Vol. 1, No. 1 (2020): 29-37.

https://ejournal3.undip.ac.id/index.php/historiografi/article/view/27806. Accessed on October 24, 2020 